\title{
The Impact of Competition Policy Enforcement on the Functioning of EU Energy Markets
}

\author{
Tomaso Duso, ${ }^{\mathrm{a}}$ Jo Seldeslachts, ${ }^{\mathrm{b}}$ and Florian Szücs ${ }^{\mathrm{c}}$
}

\begin{abstract}
We investigate the impact of competition policy enforcement on the functioning of European energy markets while accounting for sectoral regulation. For this purpose, we compile a novel dataset on the European Commission's (EC) and EU member states' competition policy decisions in energy markets and combine it with firm- and sector-level data. We find that EC merger policy has a positive and robust impact on (i) the level of competition, (ii) investment and (iii) productivity. This impact, however, only shows up in low-regulated sectors. Other competition policy tools - EC state aid control and anti-trust, as well as all member state policy variables - do not have a uniform effect on energy markets. Our findings are consistent with the idea that the EC's merger policy actions have been used to overcome obstacles to a well-functioning EU energy sector and may have contributed to the overall development of gas and electricity markets in Europe.
\end{abstract}

Keywords: Ex-post evaluation competition policy energy markets

https://doi.org/10.5547/01956574.40.5.tdus

\section{INTRODUCTION}

Competition policy enforcement in the EU energy sectors has been very active during the last decades. Since 2002, the European Commission (EC) has increasingly exercised the full range of enforcement tools at its disposal, including merger control, antitrust legislation, and state aid control. For example, since 2003 a significantly higher share of the merger cases in gas and electricity have received an in-depth investigation, thus indicating an increased level of merger scrutiny (ICF and DIW Berlin, 2015). Given this high level of activity, competition policy decisions may well have shaped the overall development of the EU gas and electricity markets. Indeed, some commentators argue that energy markets have been taken out of the domain of sector-specific regulation and put under the auspices of competition policy (Hellwig, 2008).

To shed light on whether and how competition policy has influenced European gas and electricity markets, this study examines its enforcement's impact on three crucial market outcomes: competition, investment, and productivity. Furthermore, given that regulation in energy markets has historically played an important role, we investigate if and how the degree of regulation influences this impact. Our analysis, thus, identifies the broad impact of different competition policy instruments and looks at the interaction between competition policy enforcement and energy market reg-

a Corresponding author. Deutsches Institut für Wirtschaftsforschung (DIW Berlin), TU Berlin, BCCP, CEPR, and CESifo, Mohrenstr. 58, 10117 Berlin (Germany). Email: tduso@diw.de.

b Deutsches Institut für Wirtschaftsforschung (DIW Berlin), KU Leuven, and University of Amsterdam, Mohrenstr. 58, 10117 Berlin (Germany). Email: jseldeslachts@diw.de.

c Wirtschaftsuniversität Wien, Welthandelsplatz 11020 Wien (Austria). E- Mail: florian.szuecs@wu.ac.at. 
ulation. Given their importance, both types of policies can be expected to affect market outcomes, yet little is known about their interdependencies. ${ }^{1}$

To assess this research question, we create a novel dataset that merges several sources of information. First, we create a complete map of competition policy enforcement at both the EC and the member state levels. We match these unique data with OECD data on regulation, firm-level data from the Bureau van Dijk's Amadeus/Osiris database, as well as data from the World Bank, OECD, and the European Commission.

Our results suggest that the EC's merger policy has a positive and robust impact on the level of competition, investment, and productivity. This impact, however, only shows up in low-regulated countries and sectors. Other competition policy decisions, such as EC state aid and anti-trust interventions, as well as all individual member state policy variables, do not have a consistent effect on the working of energy markets. We discuss a potential rationale for these findings: by affecting competition intensity, competition policy impacts firms' incentives to invest and, ultimately, their productivity.

The remainder of the paper is as follows. Section 2 presents the data, section 3 details the model specifications and section 4 explains and discusses the results; section 5 concludes. Appendix A gives details of data construction and estimation of outcome variables, whereas Appendix B provides two examples of competition interventions in European energy markets.

\section{DATA AND VARIABLES}

The analysis is based on data on competition policy enforcement as well as measures on regulation and market outcomes. In this section, we describe the data sources and the main variables used in the study.

\subsection{Competition policy enforcement data}

\section{EC competition cases and policy enforcement data}

To quantify the EC's activities, a detailed dataset on their enforcement in energy markets between 2005 and 2012 was created. For this purpose, we downloaded all the EC's official decisions in energy markets (NACE code D35) from its website. We used the decision date as the criterion for the selection and included all cases where the Commission's decision was made between January 1, 2005, and December 31, 2012. There were 200 merger decisions, 17 antitrust decisions (16 abuses and 1 cartel), and 203 state aid decisions concerning energy markets during the relevant sample period.

We then allocated these decisions to countries in order to match the main level of analysis proposed in this study, i.e. the member state/year unit of observation. In state aid cases and in most of the antitrust cases, only one country is involved. Therefore, these cases are supposed to only affect that specific national market and are easily allocated to the particular member state involved. Mergers, on the other hand, are often more complex. In most cases handled by the EC, the market definition includes several countries. If the market definition was broader than national, we allocated the case to all member states involved in that decision. If the market definition was EU-wide, all EU

1. But see Mulder (2015) for a competition analysis of the Dutch Electricity markets, and Lise and Hobbs (2009) and Zwart (2009) for pan-European simulations on the topic. See also Brau et al. (2010) and Percebois (2008) for the direct impact of regulatory reforms in European energy markets.

All rights reserved. Copyright (C) 2019 by the IAEE. 
Figure 1: (a) EC merger cases; (b) EC state aid cases; (c) EC merger enforcement; (d) EC state aid enforcement; (e) EC abuse and cartel cases (=enforcement)

(a)

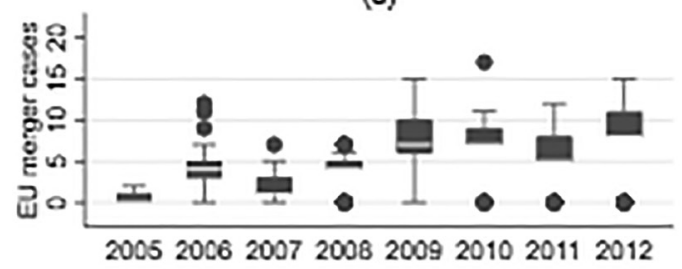

(c)

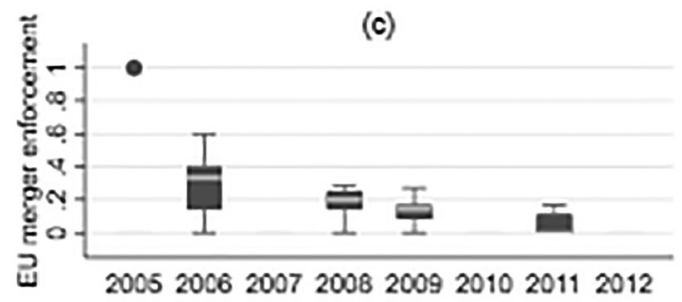

(e)

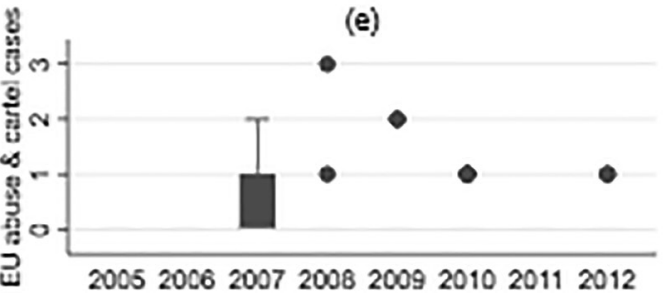

(b)

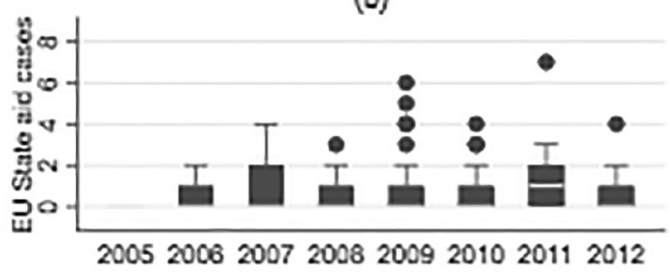

(d)

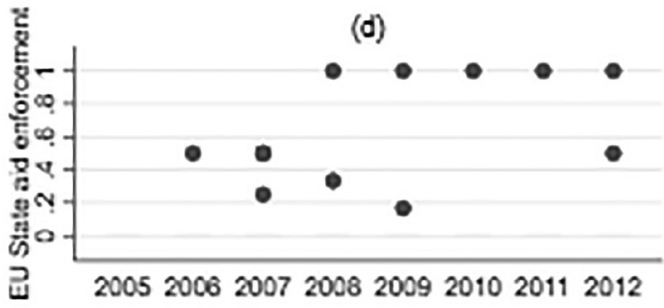

countries in our sample are considered to be affected by the decision. If the market definition was left open, we allocated the case to the countries of origin of the merging firms.

Variables measuring the number of mergers and state aid cases are used as key control variables to capture the level of activity since they could have themselves an impact on market outcomes (Clougherty and Seldeslachts, 2013). For example, a large energy merger such as GDF's acquisition of Suez in 2006 might have had an impact on investment in the relevant markets (Argentesi et al., 2017). ${ }^{2}$ Figures $1 \mathrm{a}$ and $1 \mathrm{~b}$ show the evolution of the merger and state aid cases in box- and whisker plots; mergers are considerably more frequent than state aid cases. We define then an EC merger intervention as follows: all merger remedies, plus merger withdrawals during phase $2 .{ }^{3}$ In the case of state aid, we define an intervention as the decision to initiate a formal investigation; EC officials agreed that this is the best (albeit imperfect) indicator of intervention in this area. In the case of mergers and state aid, the measures of intensity of competition policy enforcement used in the regressions are then defined as the ratio between the number of interventions and the number of notified cases, as this ratio gives an indication of how often the EC intervenes per notified case

2. To give further insights in the cases we have coded in the data, we provide for this example more details in Appendix B. Additionally, we provide details for an abuse of dominance case there as well.

3. When a merger is notified, the EC has an initial timeframe of 25 working days for a first assessment (phase 1). Should a more in depth investigation be required, the EC can initiate phase 2 proceedings, lasting for up to 90 additional working days. A withdrawal in phase 2 by merging parties is often due to a breakdown of the bargaining process between parties and EC, which de facto is often equivalent to a prohibition (Clougherty et al., 2016). While prohibitions should be considered the most extreme form of intervention, no merger was prohibited in the energy sector during the sample period.

Copyright (C) 2019 by the IAEE. All rights reserved. 
Table 1: Variable definitions

\begin{tabular}{|c|c|}
\hline Outcomes & \\
\hline Beta & $\begin{array}{l}\text { Elasticity of relative profits with respect to relative costs per year, country and } \\
\text { industry cluster (see Appendix A) }\end{array}$ \\
\hline Investment & Yearly change in firm-level fixed assets, in million Euros \\
\hline TFP & $\begin{array}{l}\text { Total factor productivity, estimated from a translog production function, at the } \\
\text { firm/year level (see Appendix A) }\end{array}$ \\
\hline \multicolumn{2}{|l|}{ Competition policy enforcement } \\
\hline EC merger enforcement & $\begin{array}{l}\text { Number of mergers cases with intervention by the EC, divided by merger } \\
\text { notifications, at the member state/year level }\end{array}$ \\
\hline EC state aid enforcement & $\begin{array}{l}\text { Number of state aid cases investigated by the EC, divided by number of state aid } \\
\text { cases notified, at the member state/year level }\end{array}$ \\
\hline EC abuse \& cartel enforcement & $\begin{array}{l}\text { Number of abuse of dominance cases and cartels prosecuted by the EC, at the } \\
\text { member state/year level }\end{array}$ \\
\hline National cartel fines & $\begin{array}{l}\text { Total amount of fines imposed by NCAs in cartel and antitrust cases, at the } \\
\text { member state/year level }\end{array}$ \\
\hline National merger enforcement & $\begin{array}{l}\text { Number of mergers with intervention by NCAs, divided by number of merger } \\
\text { notifications, at the member state/year level }\end{array}$ \\
\hline National cartel \& abuse cases & $\begin{array}{l}\text { Number of abuse of dominance cases and cartels prosecuted by NCAs, at the } \\
\text { member state/year level }\end{array}$ \\
\hline \multicolumn{2}{|l|}{ Control variables } \\
\hline EC merger cases & Number of mergers notified to EC, at the member state/year level \\
\hline EC state aid cases & Number of state aid cases notified to EC, at the member state/year level \\
\hline National merger cases & Number of mergers cases notified to NCAs, at the member state/year level \\
\hline Regulation (OECD indicator) & Average regulatory intensity of energy markets, at the member state/year level \\
\hline Electricity capacity (combustible) & Total energy capacity, combustible fuels, at the member state/year level \\
\hline Electricity capacity (nuclear) & Total energy capacity, nuclear, at the member state/year level \\
\hline Electricity capacity (renewable) & Total energy capacity, renewables, at the member state/year level \\
\hline Energy imports (\% of tot. cons.) & Percentage of total energy consumption imported \\
\hline GDP per capita & GDP per capita in thousand $€$, at the member state/year level \\
\hline Population growth & Population growth in $\%$, at the member state/year level \\
\hline Leader productivity & $90^{\text {th }}$ percentile of Total Factor Productivity (TFP), by sector and year \\
\hline Sector inquiry & $\begin{array}{l}\text { Dummy variable indicating the EC's } 2007 \text { sector inquiry into energy and gas } \\
\text { markets }\end{array}$ \\
\hline
\end{tabular}

(see Clougherty and Seldeslachts, 2013, for a rationale). Figure 1c illustrates that the Commission intervened in a sizeable fraction of energy mergers, whereas state aid programs, on the other hand, are not so frequently so investigated (see Figure 1d).

For abuses and cartels, we simply use the number of opened cases as a measure of enforcement, as of course these anti-trust cases are not first notified to the EC before being investigated. From Figure 1e, one can observe that few cartel and abuse cases were opened during the sample period. Table 1 defines all these and subsequent variables, while Table 2 summarizes the indicators of activity and EC competition policy enforcement.

\section{National competition cases and policy enforcement data}

Constructing measures of national competition policy enforcement was a more significant challenge and we see the collection of these data as an important contribution of the current study. Since no clear source of data is available, we created a questionnaire that was sent to all national competition authorities (NCAs) in the EU. ${ }^{4}$ Based on this information, we constructed measures of national competition policy enforcement in a similar fashion as for the EC, with the exception that

4. We gratefully acknowledge the support we had in this data collection exercise through DG Competition of the European Commission, the European Competition Network, and the National Competition Authorities. Without their extensive 
Table 2: EC competition policy enforcement at the member state/year level: Descriptive statistics

\begin{tabular}{|c|c|c|c|c|c|}
\hline Variable & Obs. & Mean & St. Dev. & Min. & Max. \\
\hline \multicolumn{6}{|l|}{ Mergers } \\
\hline EC merger cases & 216 & 4.54 & 4.01 & 0 & 17 \\
\hline EC merger enforcement & 216 & 0.08 & 0.14 & 0 & 1 \\
\hline \multicolumn{6}{|l|}{ State aid } \\
\hline EC state aid cases & 216 & 0.68 & 1.16 & 0 & 7 \\
\hline EC state aid enforcement & 216 & 0.04 & 0.17 & 0 & 1 \\
\hline \multicolumn{6}{|l|}{ Antitrust } \\
\hline EC abuse \& cartel cases/enforcement & 216 & 0.14 & 0.47 & 0 & 3 \\
\hline
\end{tabular}

Table 3: National competition policy enforcement at the member state/year level: Descriptive statistics

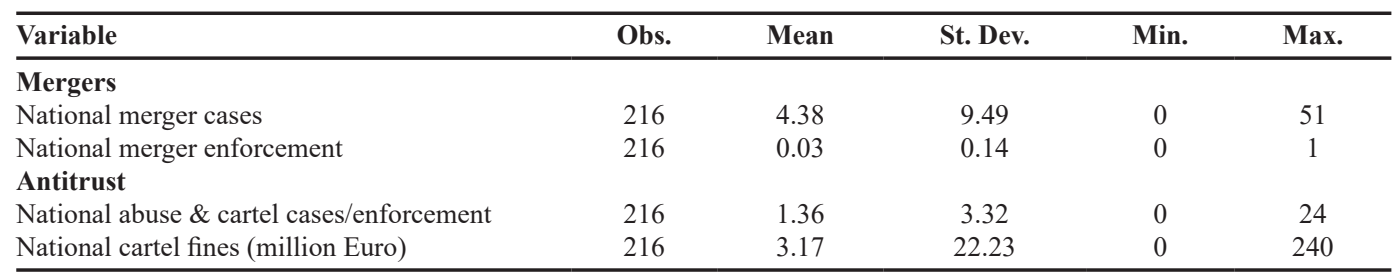

there are no state aid control cases at the national level. On the other hand, we obtained usable data on national cartel fines. ${ }^{5}$ Table 3 shows the descriptive statistics for these variables.

The dynamics of national competition cases and policy enforcement variables are also represented through box and whiskers plots (Figure 2). Although not visible in these figures, there is some variation in merger notifications at the country level. While some large member states-particularly Germany and Italy_average more than 30 energy mergers per year, some smaller member states have very little or no activity. This holds also true for cartels and dominance cases, where Germany and Poland show most activity.

In terms of enforcement, although national competition policy enforcement is rather low on average (the country/year observations are zero up to the $75^{\text {th }}$ percentile), there is some variation across countries and time (see Figures $2 \mathrm{~b}$ and $2 \mathrm{c}$ ).

\subsection{Regulation}

Apart from competition enforcement, regulation is the other important policy dimension in our study. The OECD Indicators from the Product Market Regulation project, specifically the indicators of regulation in energy, transport, and communication (ETCR), are used as measures of intensity of regulation. ${ }^{6}$ This is the most comprehensive, accurate, and widely used database to mea-

help, it would not have been possible to create this dataset. Austria is missing from the sample because the NCA was unable to supply us with data.

5. There were too few cartels detected by the EC in the time frame for their fines to be useful for econometric analysis and, thus, EC fines are omitted from our analysis. While we did get usable data on cartel fines from the NCAs, we only received aggregated data at the country/year level. Therefore, we have no information on the number of firms in each of the fined cartels. The potential shortcoming of this variable is that total fines might not only be an indicator of the NCA's toughness, which is the intended aim of this variable in our analysis, but also of the size of the cartel.

6. Data is available at https://stats.oecd.org/Index.aspx?DataSetCode=ETCR (last accessed 7. August 2018). Bulgaria, Croatia, Latvia, Lithuania and Romania were dropped because product market regulation data is unavailable for these countries. Our indicator is the average of four sub-indicators measuring the degree of public ownership, entry regulation, vertical 
Figure 2: (a) National merger cases; (b) National merger enforcement; (c) National cartel and abuse cases (=enforcement)

(a)

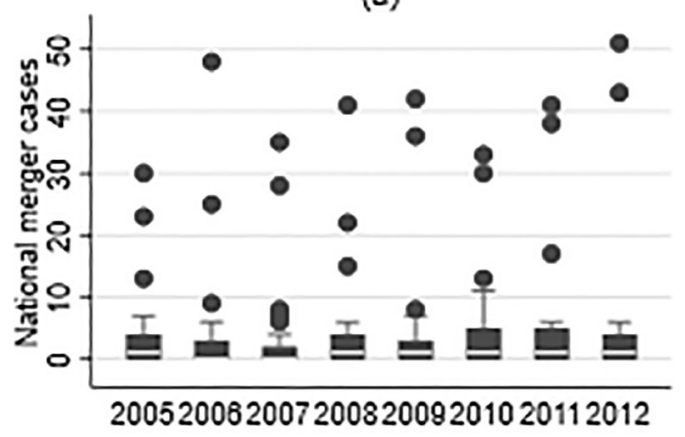

(c)

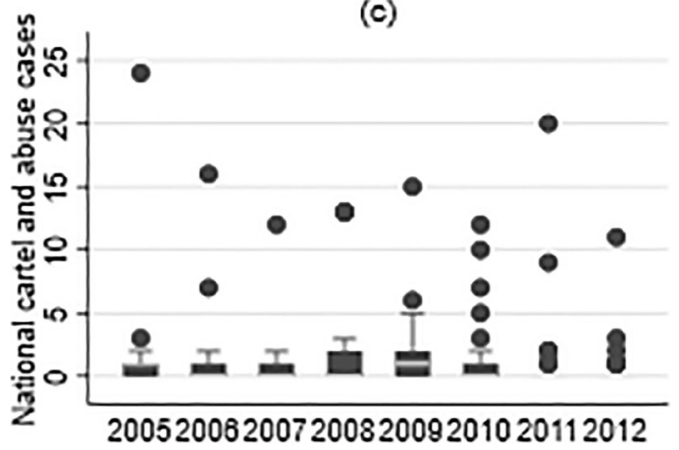

(b)

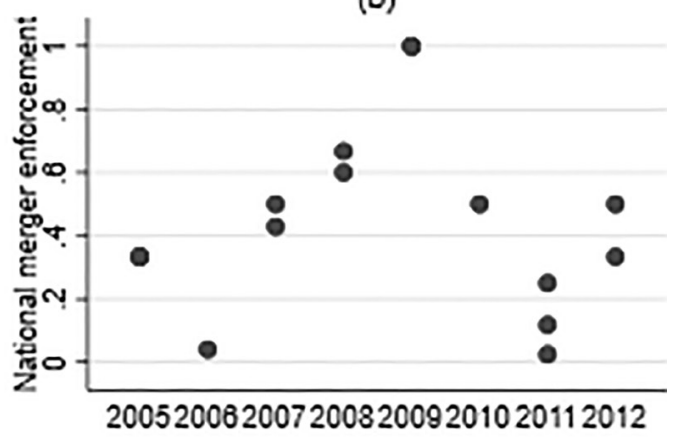

sure the effect of regulation on market outcomes (e.g. Alesina et al., 2005; Duso and Seldeslachts, 2011; Bourlès et al., 2013). It must be noted though that, while being the most complete database on regulation, it still does not include all relevant dimensions. For example, it cannot capture the recent trends of several member states to incentivize investments in new grids through several support schemes.

Figure 3 shows box plots of the regulation indicator over the 2005-2012 period. On average, regulatory pressure has decreased over the years. At the same time, the regulatory environment in markets varies across Europe. For example, energy markets are more liberalized in Germany, Spain and the UK than in Estonia, Greece and Poland.

In our analysis, we distinguish between high and low regulation countries by splitting the sample at the median of regulatory intensity for each member state and year. This has the advantage of providing us with subsamples of equal size. We will separately analyze the effect of competition policy in the sub-samples of high- vs. low- regulated countries/periods. We choose to use sub-samples based on this dichotomous definition of high- vs. low-regulation rather than interactions between competition policy enforcement and the continuous regulatory indexes to better exploit the rather limited variation in the data. While the second option would allow a precise fine-tuning of the interaction effects, it might fail to deliver clear-cut results due to the too scarce time-series vari- 
Figure 3: Regulation of EU energy markets over time

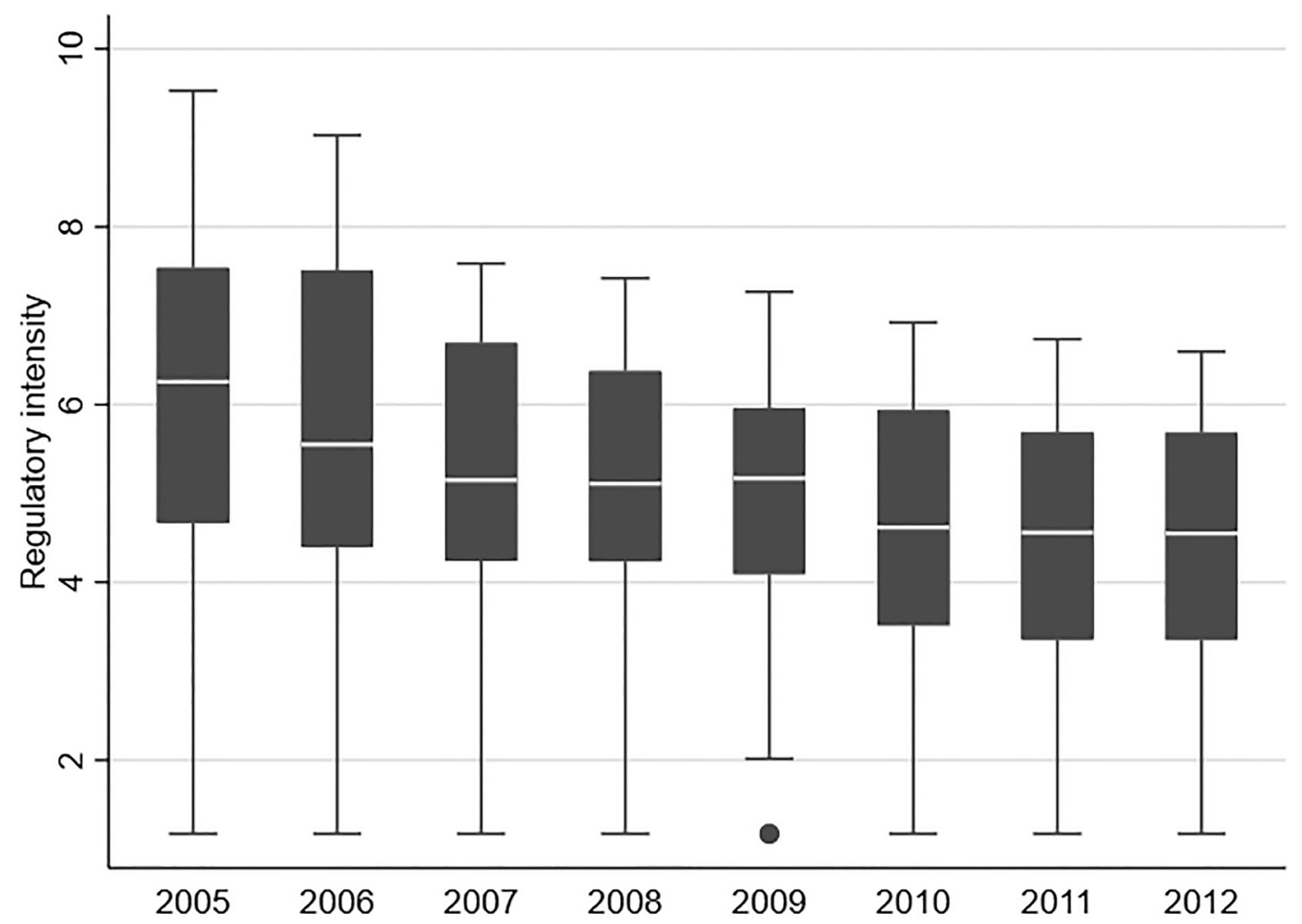

ation in both variables. We therefore consider our approach to deliver more robust and more easily interpreted findings.

\subsection{Outcome variables}

We focus on three key market outcome measures: intensity of competition, investment, and productivity. All data to measures these outcomes was obtained from the Amadeus/Osiris database. We focus only on the 2005-2012 period since this is the coverage of our competition policy enforcement data. We further concentrate on large firms active in energy markets, as only these firms are expected to (strongly) react to changes in the competitive environment and to engage in significant investment activities that might lead to productivity gains. Over the entire sample period, we observe 1,438 different firms operating in 19 countries. Further details on this data can be found in Appendix A.

\section{Intensity of competition}

Intensity of competition is naturally defined at the market-level. Well-defined product markets as used in competition cases would be desirable but are not feasible for a study of this scope. The industry codifications based on NACE codes represent the best alternative to define relevant sectors and are available for each firm in our sample. We therefore define three main markets that correspond to the sectors production $\&$ generation, transmission and trade.

We use the elasticity of relative profits with respect to relative costs, i.e., 'Boone's Beta,' as measure of competition (Boone, 2008). This indicator is based on the idea that when a market is 
more competitive, then firms that have relatively lower costs can earn relatively higher profits in this industry. In particular, Boone (2008) shows that for three efficiency levels $n_{1}>n_{2}>n_{3}$ and a level of competition intensity $\theta$, it is the case that

$$
\frac{d\left(\frac{\pi\left(n_{1}, \theta\right)-\pi\left(n_{3}, \theta\right)}{\pi\left(n_{2}, \theta\right)-\pi\left(n_{3}, \theta\right)}\right)}{d \theta}>0,
$$

where $\pi\left(n_{i}, \theta\right)$ are a firm's $i$ variable profits. Thus, relative variable profit differences are increasing in the intensity of competition, $\theta$. These betas are an indication of the intensity of competition. In particular, the more negative beta is, the more firms are being 'punished' for being inefficient. Thus, if a policy serves to increase competition, this would result in a lower Beta.

This measure is particularly useful in markets that are subject to intense reallocation dynamics, since it is monotonic with respect to the direction of the competition shock. In particular, it increases in absolute value with higher competition arising from lower entry barriers, as well as from reallocation of output to more efficient incumbent firms within the sector. ${ }^{7}$ One further key advantage of this measure is that it holds for any subset of firms within one market. The details for the construction of this variable can be found in Appendix A.

\section{Investment}

Investment is particularly relevant as an outcome variable in energy markets as it is widely accepted that more investment is needed in Europe's energy sectors in order to ensure the security of supply and to improve efficiency. Indeed, to meet the EU's ambitious climate and energy targets, and at the same time secure the provision of energy, companies are expected to increasingly invest in electricity generation capacity - particularly in renewable energies - as well as in national and cross-national infrastructure projects, such as interconnector transmission grids (Hirschhausen et al., 2014). We follow Grajek and Röller (2012), who use measures of investment defined as the change in fixed assets owned by the firms. Specifically, we calculate investment $I$ of firm $i$, in sector $s$, country $c$ and year $t$ as the yearly change in firm-specific fixed assets:

$$
I_{i s c t}=F A_{i s c t}-F A_{i s c t-1} .
$$

This variable is not a perfect measure, but it is the best available indicator of investment for a study like ours. The main advantage is that fixed assets are observable for all firms present in the different sectors of energy markets and can be easily compared. On the downside, we cannot precisely identify the type of investment carried out by the firms.

\section{Total Factor Productivity}

Finally, we estimate the level of total factor productivity (TFP) as the residual from an industry-specific, firm-level translog production function. In particular, we calculate total factor

7. Markups are often used as a measure of competition. However, markups have problems to consistently pick up the following two ways in which competition can be intensified in a market: (i) having more firms in a market due to a fall in entry barriers; and (ii) a more aggressive conduct by incumbent firms. In the former case, more firms in the market reduce mark-ups in standard models. In the latter case markups can go up in response to an increase in competition intensity, incorrectly suggesting that competition went down (Amir, 2002; Bulow and Klemperer, 1999; Stiglitz, 1989). Boone's measure does not suffer from these problems. See e.g. Van Leuvensteijn et al. $(2011,2013)$ for applications in the banking market.

All rights reserved. Copyright (C) 2019 by the IAEE. 
productivity of firm $i$ in sector $s$, country $c$ and year $t$ as the residual of a sector-specific $(s)$, translog production function:

$$
T F P_{i s c t}=\ln V A_{i s c t}-f_{s}\left(\ln K_{i s c t}, \ln L_{i s c t}, \ln M_{i s c t}\right),
$$

where $V A_{\text {isct }}$ is the value added of firm $i$ in year $t, K_{i s c t}, L_{i s c t}$, and $M_{i s c t}$ represent its capital, labor and material expenditures, respectively. See Appendix A for exact definition and estimation details. Table 4 presents the yearly summary statistics for our estimations and calculations of Boone's Beta, investment and TFP.

\subsection{Control variables}

We use several additional sources to construct control variables. To account for differing institutional qualities across EU member states, we use data sourced from the World Bank (GDP per capita, population growth, energy imports as a share of total energy consumption). ${ }^{8}$ Information on the energy mix - i.e. the share of different fuels in energy production - used in different countries are obtained from the Commission's energy's fact sheets. ${ }^{9}$ These are country-specific existing production capacities in combustible fuels, nuclear and renewable energy. These variables are included since (excess) capacities are potentially important factors in determining the level of competition and the investment incentives in an industry.

\section{MODEL SPECIFICATION}

Our econometric framework builds on recent empirical literature analyzing the link between policy enforcement and market outcomes; specifically, on the impact of regulation on investment (Alesina et al., 2005; Lyon and Mayo, 2005; Grajek and Röller, 2012; Cambini and Rondi, 2010); and on the relationship between competition enhancing policies and productivity (Aghion et al., 2009; Buccirossi et al., 2013; Bourlès et al., 2013). Given that we use different dependent variables - as well as levels of aggregation - the specific models differ slightly, as further explained below.

\subsection{Sector-level competition outcomes}

Since competition is defined at the market-level, we conduct our first analysis at the country-sector-year level. Hence, the estimated coefficients measure the impact of policy enforcement on Boone's Beta, after controlling for other observable shifters. Specifically, we estimate the following specification:

$$
Y_{s c t}=\gamma E C E n f_{c t-1}+\delta N a t E n f_{c t-1}+\beta \operatorname{Reg}_{c t-1}+\rho Z_{c t-1}+\omega_{c}+\omega_{s}+\omega_{t}+\varepsilon_{s c t},
$$

where $Y_{s c t}$ is the competitive outcome -i.e. the Boone's Beta-in sector $s$, in country $c$, at time $t$. The vectors ECEnf ${ }_{c t-1}$ and NatEnf $f_{c t-1}$ are lags of the measures of competition policy enforcement at the $\mathrm{EC}$ and NCA levels, respectively, covering the different policy areas (mergers, abuse of dominance and cartel cases and, for the EU, state aid control). The variable $\operatorname{Reg}_{c t-1}$ denotes the intensity of regulation in a given national market $c$ in year $t-1$, measured by using the OECD regulation index for

8. Data available at https://data.worldbank.org/ (last accessed 7. August 2018).

9. Data available at https://ec.europa.eu/energy/en/data-analysis/country (last accessed 7. August 2018).

Copyright (C) 2019 by the IAEE. All rights reserved. 


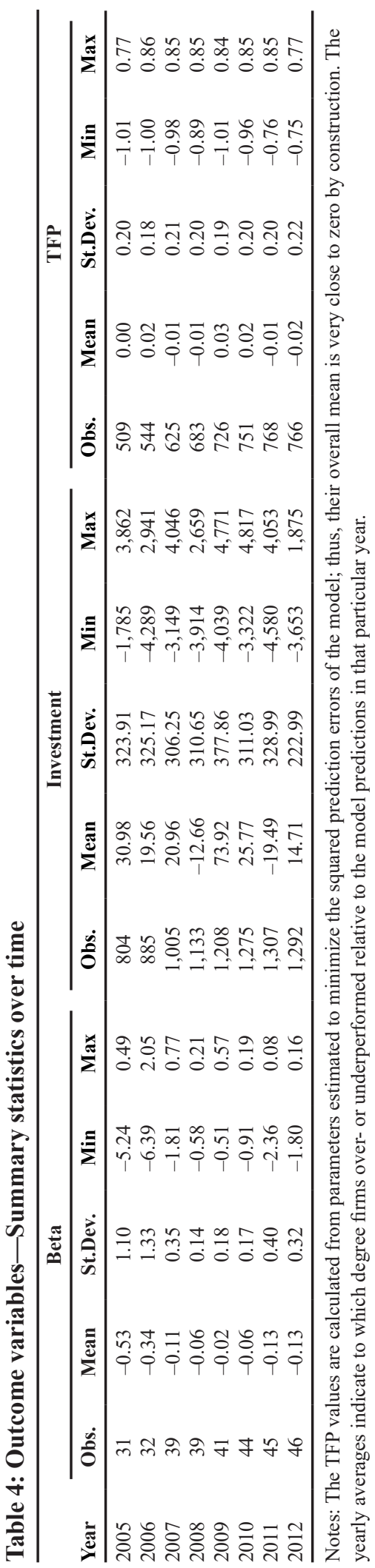

All rights reserved. Copyright (C) 2019 by the IAEE. 
the energy sectors. All estimations are performed by applying the OLS estimator with fixed effects in the statistical package Stata (using the areg command).

To more cleanly identify the effect of enforcement, we need to control for the number of merger cases notified to the Commission as well as for the number of notified state aid cases, as they are, of course, important drivers of the level of competition (Seldeslachts et al., 2009). We also control for time-varying country-specific factors, such as GDP per capita and population growth, as well as the share of imports in total energy consumption $\left(Z_{c t-1}\right)$. Additionally, the same vector includes country-specific existing production capacities in combustible fuels, nuclear and renewable energy. Finally, we control for unobserved time-invariant country-sector specific heterogeneity by means of country and sector fixed-effects $\left(\omega_{c}\right.$ and $\left.\omega_{s}\right)$, as well as unobserved firm-invariant time-specific aggregate heterogeneity by means of year fixed-effects $\left(\omega_{t}\right)$. The error term $\varepsilon_{s c t}$ is assumed to be correlated among observations within the same country-sector, and thus errors are clustered at the country-sector level. All explanatory variables are lagged by one period to reduce endogeneity issues due to reverse causality.

One could imagine that it takes longer than one year for competition policy to affect market outcomes, such as TFP. We ran robustness checks on all our specifications with one additional lag for all our policy variables. Results are qualitatively the same even though the number of observations drops due to the additional lag. That is also the reason why we present the specifications with only one lag. The issue of identification is further discussed in the following section.

\subsection{Firm-specific investment and productivity}

The second level of analysis focuses on firm-level outcomes: investment and productivity. Following recent literature, we identify the effect of policy on outcomes by looking at the relationship between country-specific measures of enforcement and firm-specific outcomes (Pavcnick, 2002; Buccirossi et al., 2013; Bourlès et al., 2013). Our estimated model is represented by the following equation:

$$
Y_{i s c t}=\gamma \operatorname{ECEnf}_{c t-1}+\delta N a t E n f_{c t-1}+\beta \operatorname{Reg}_{c t-1}+\rho Z_{c t-1}+\omega_{i s c}+\omega_{t}+\varepsilon_{i s c t} .
$$

$Y_{i s c t}$ is now a firm-specific outcome - investment or total factor productivity —of firm $i$ in country $c$, in sector $s$, at time $t$. The explanatory variables are the same as discussed above. The inclusion of more fine-grained firm fixed-effects $\left(\omega_{i s c}\right)$ in the model makes the use of country and/or sector fixed effects obsolete. The error terms are clustered at the country level.

When we employ productivity, we further augment the model to account for the distance to the technological frontier (Aghion et al., 2009). Therefore, we add the productivity of the leading firm(s) in the specific industry and year as an additional control variable to our basic regression. This leader productivity measure is defined as the $90^{\text {th }}$ percentile of firm-level productivities in that particular sector and year.

\subsection{Competition policy and regulation}

We separately analyze the effect of competition policy in the sub-samples of high- vs. lowregulated countries/periods, by using the median of the overall regulation index for each member state and year. We assign sectors and firms to the high-regulation sub-sample if the value of the regulation index in that country and year is higher than the median of the OECD regulation index over all countries and time periods in our sample. Conversely, a country is low-regulated if the index takes a value lower than the median. In this way, we use not only the cross-sectional but also the 
time variation in the measures of regulation, as countries can move from one to the other sub-sample over time by implementing regulatory reforms. ${ }^{10}$

\section{RESULTS}

\subsection{Intensity of competition}

We begin with the analysis of the link between competition policy enforcement and the level of competition. In this model, the outcome variable of interest is the country/sector Boone's Beta. Remember that this measure of competition intensity reflects the negative relationship between profits and cost efficiency faced by firms in a competitive environment. Thus, a decrease in this measure can be interpreted as an increase in competition. To facilitate the comparison of the coefficients' estimates of the various explanatory variables that are measured in different units, we report standardized beta coefficients. Therefore, the measured effects represent the change in standard deviations of the dependent variable due to a one standard deviation change in the variable of interest.

We find a negative and significant impact of EC merger enforcement on Boone's Beta in low-regulated countries, as Table 5 shows. In particular, a standard deviation increase in EC merger enforcement relates to a decrease in the relative profit elasticity by 0.484 standard deviations in the sub-sample of low-regulated countries - thus increasing competition. The effect is (much) smaller and non-significant in high-regulated markets and overall. ${ }^{11}$

On the contrary, other measures of enforcement are mostly not significant. Only the number of national cartel and abuse investigations significantly reduces Beta in the sub-sample of high-regulated countries. State aid schemes, on the other hand, have a significant positive impact on the relative profit's elasticity and, thus, reduce competition. This should perhaps not come as a surprise, since state aid may have a distortive effect on competition. Finally, national mergers decrease Beta, and thus increase competition. This indicates that national energy mergers might have led, on average, to efficiency gains and therefore have induced a more competitive environment. For the sake of brevity, we do not discuss the impact of the control variables that are not directly related to the aim of the study in these and the following estimations.

\subsection{Investment}

Table 6 shows the estimation results of the impact of competition policy on investment. We find a significant positive relationship between the enforcement of EC merger control and firms'

10. Energy markets in Germany, Hungary, Italy, Spain and the UK fall into the lowly regulated category over the entire sample period. Conversely, Denmark, Finland, France, Ireland, Poland and Slovakia are always under a high-regulation regime. Finally, the energy markets in Belgium, the Czech Republic, the Netherlands, Portugal and Sweden are deregulated over time and move from a high regulation to a low regulation regime.

11. As explained in Appendix A, we estimate Boone's Beta for the different segments - production, transmission, and trade - for each country and year. However, to increase econometric efficiency and number of observations, we pool the observations for these sectors when we look at the impact of competition policy enforcement. Thus, we do not separately estimate the effect of competition policy in the three sectors. Nevertheless, when we split the effect of EC merger enforcement for the three different segments, we find the following results: First, the impact of EC merger policy enforcement has a negative impact on Boone's Beta - and thus a positive impact on competition — in the energy production sector when we use the full sample. Second, EC merger policy enforcement has only a negative impact on Boone's Beta in the transmission and trade sectors when these sectors are characterized by low regulation. This confirms the intuition that production is the sector where competition policy enforcement has potentially the largest impact, as this sector is in general less regulated than the transmission and trade sectors. We thank an anonymous referee for making this logic clear.

All rights reserved. Copyright (C) 2019 by the IAEE. 
Table 5: The impact of competition policy variables on Boone's Beta

\begin{tabular}{|c|c|c|c|c|c|c|}
\hline & \multicolumn{2}{|c|}{ Full sample } & \multicolumn{2}{|c|}{ Low Regulation } & \multicolumn{2}{|c|}{ High Regulation } \\
\hline & Coeff. & t-stat. & Coeff. & t-stat. & Coeff. & t-stat. \\
\hline EC merger enforcement ${ }_{t-1}$ & -0.274 & $(-1.59)$ & $-0.484 * * *$ & $(-6.14)$ & -0.040 & $(-0.29)$ \\
\hline EC state aid enforcement $t_{t-1}$ & -0.018 & $(-0.38)$ & -0.018 & $(-0.36)$ & -0.012 & $(-0.15)$ \\
\hline EC abuse \& cartel enforcement $t_{t-1}$ & 0.056 & $(0.73)$ & -0.242 & $(-1.58)$ & 0.049 & $(1.02)$ \\
\hline National merger enforcement ${ }_{t-1}$ & -0.021 & $(-0.56)$ & -0.021 & $(-0.99)$ & 0.120 & $(1.62)$ \\
\hline National cartel fines & $0.056^{*}$ & $(1.79)$ & 0.094 & $(1.13)$ & 0.018 & $(0.46)$ \\
\hline National abuse \& cartel cases ${ }_{t-1}$ & -0.403 & $(-1.29)$ & 0.245 & $(1.27)$ & $-1.364 * *$ & $(-3.02)$ \\
\hline Sector inquiry $_{t-1}$ & 0.273 & $(1.47)$ & 0.094 & $(0.74)$ & $0.254 *$ & $(2.14)$ \\
\hline Regulation $(\mathrm{OECD} \text { index })_{\mathrm{t}-1}$ & -0.078 & $(-0.15)$ & -0.303 & $(-0.58)$ & -0.573 & $(-1.67)$ \\
\hline EC merger cases ${ }_{t-1}$ & -0.016 & $(-0.11)$ & -0.134 & $(-0.53)$ & -0.066 & $(-0.51)$ \\
\hline State aid cases ${ }_{t-1}$ & 0.089 & $(1.03)$ & -0.341 & $(-1.61)$ & $0.197 * *$ & $(2.34)$ \\
\hline National merger cases & $-0.379 *$ & $(-2.04)$ & 0.016 & $(0.06)$ & -0.055 & $(-0.33)$ \\
\hline Electricity capacity (combustible) & -1.544 & $(-0.99)$ & -3.063 & $(-1.14)$ & $3.568^{*}$ & $(2.16)$ \\
\hline Electricity capacity (nuclear) & 15.310 & $(0.82)$ & $10.327 *$ & $(2.00)$ & -14.539 & $(-1.11)$ \\
\hline Electricity capacity (renewable) ${ }_{\mathrm{t}-1}$ & 0.811 & $(1.38)$ & 0.621 & $(0.83)$ & $-2.011^{* *}$ & $(-2.67)$ \\
\hline GDP per capita & -0.934 & $(-0.77)$ & -2.628 & $(-1.08)$ & -1.966 & $(-0.59)$ \\
\hline Population growth & 0.111 & $(0.75)$ & 0.104 & $(0.27)$ & 0.262 & $(0.90)$ \\
\hline Energy imports ( $\%$ of tot. cons) $)_{t-1}$ & 1.288 & $(1.09)$ & $1.556^{* *}$ & $(2.47)$ & $1.579 * *$ & $(2.67)$ \\
\hline R-squared & \multicolumn{2}{|c|}{0.20} & \multicolumn{2}{|c|}{0.60} & \multicolumn{2}{|c|}{0.36} \\
\hline Observations & \multicolumn{2}{|c|}{251} & \multicolumn{2}{|c|}{126} & \multicolumn{2}{|c|}{125} \\
\hline
\end{tabular}

Notes: The level of observation is country-sector-year. The dependent variable is the sector-country specific elasticity of relative profits with respect to relative costs, Boone's Beta. All independent variables are lagged one year. We report standardized coefficients. Standard errors are robust and clustered at the country level. The t-statistics are reported in parentheses. We control for country (16) and sector (3) fixed-effects as well as year dummies. The symbols ***, **, * represent $1 \%, 5 \%$, and $10 \%$ significance level respectively.

Table 6: The impact of competition policy variables on investment

\begin{tabular}{|c|c|c|c|c|c|c|}
\hline & \multicolumn{2}{|c|}{ Full Sample } & \multicolumn{2}{|c|}{ Low Regulation } & \multicolumn{2}{|c|}{ High Regulation } \\
\hline & Coeff. & t-stat. & Coeff. & t-stat. & Coeff. & t-stat. \\
\hline EC merger enforcement $t_{t-1}$ & -0.007 & $(-0.31)$ & $0.226^{* * *}$ & (2.90) & -0.006 & $(-0.20)$ \\
\hline EC State aid enforcement $t_{t-1}$ & -0.001 & $(-0.07)$ & - & - & -0.008 & $(-0.38)$ \\
\hline EC abuse \& cartel enforcement ${ }_{t-1}$ & 0.020 & $(0.51)$ & $-0.265^{* * *}$ & $(-2.60)$ & $0.059 * *$ & $(2.29)$ \\
\hline National merger enforcement ${ }_{t-1}$ & 0.008 & $(0.36)$ & 0.002 & $(0.05)$ & 0.005 & $(0.26)$ \\
\hline National cartel fines $_{t-1}$ & -0.003 & $(-0.11)$ & -0.038 & $(-0.34)$ & -0.018 & $(-1.01)$ \\
\hline Sector Inquiry $t_{t-1}$ & 0.058 & $(1.07)$ & -0.059 & $(-0.65)$ & 0.062 & $(1.23)$ \\
\hline Regulation (OECD indicator) $)_{t-1}$ & 0.178 & $(1.67)$ & $2.815^{* * *}$ & $(3.30)$ & 0.153 & $(1.59)$ \\
\hline EC merger cases ${ }_{t-1}$ & -0.037 & $(-1.49)$ & $-0.378 * * *$ & $(-2.87)$ & -0.060 & $(-1.10)$ \\
\hline State aid cases ${ }_{t-1}$ & 0.029 & $(1.55)$ & $0.195 * *$ & $(2.37)$ & 0.024 & $(0.91)$ \\
\hline National merger cases $_{t-1}$ & 0.015 & $(0.27)$ & -0.210 & $(-0.63)$ & 0.010 & $(0.12)$ \\
\hline National abuse \& cartel cases ${ }_{t-1}$ & 0.020 & $(0.70)$ & 0.008 & $(0.08)$ & 0.065 & $(1.20)$ \\
\hline Electricity capacity (combustible) ${ }_{t-1}$ & -0.627 & $(-1.52)$ & -0.486 & $(-0.72)$ & -0.604 & $(-1.44)$ \\
\hline Electricity capacity (nuclear) ${ }_{t-1}$ & -0.448 & $(-1.00)$ & $9.016^{* * *}$ & $(3.46)$ & 4.234 & $(1.40)$ \\
\hline Electricity capacity (renewable) ${ }_{t-1}$ & $0.329 * *$ & $(2.54)$ & $0.909 * * *$ & $(2.66)$ & $0.223 *$ & $(1.70)$ \\
\hline GDP per capita $_{t-1}$ & $-0.676 * *$ & $(-2.56)$ & -0.577 & $(-1.20)$ & -0.621 & $(-1.53)$ \\
\hline Population growth $t_{t-1}$ & $0.088^{*}$ & $(1.99)$ & $0.654 * * *$ & $(5.29)$ & 0.034 & $(0.83)$ \\
\hline Energy imports ( $\%$ of tot. cons $)_{\mathrm{t}-1}$ & 0.077 & $(0.62)$ & 0.288 & $(0.86)$ & 0.223 & $(1.14)$ \\
\hline R-squared & \multicolumn{2}{|c|}{0.17} & \multicolumn{2}{|c|}{0.18} & \multicolumn{2}{|c|}{0.21} \\
\hline Observations & \multicolumn{2}{|c|}{8,344} & \multicolumn{2}{|c|}{4,098} & \multicolumn{2}{|c|}{4,246} \\
\hline
\end{tabular}

Notes: The unit of observation is firm-country-year. The dependent variable is firm level investment. All independent variables are lagged one year. We report standardized beta coefficients. Standard errors are robust and clustered at the country level. The t-statistics are reported in parentheses. We control for firm fixed-effects as well as year dummies. The symbols $* * *, * *, *$ represent $1 \%, 5 \%$, and $10 \%$ significance level respectively. 
investment in the sub-sample of low-regulated countries. In particular, a one standard deviation increase in the merger interventions increases firm-level investment by 0.226 standard deviations.

Few of the other competition policy enforcement variables have a significant effect on investment. Only EC cartel and abuse cases significantly increase investment in high-regulated markets, while significantly decreasing it in low-regulated markets. We further estimate a positive and significant coefficient for state aid programs in low-regulated countries. These programs often aim to support companies in financial distress and might be expected to have been used to acquire additional assets, thus increasing investment. EC-level mergers, on the other hand, have a negative effect on investment overall, mainly driven by their negative impact in low-regulation industries. This finding tentatively contradicts the often-heard common wisdom that larger firms invest more.

We further estimated a (non-reported) autoregressive model where we added the lagged dependent variable as an additional regressor. This augmented model potentially allows us to more precisely specify the investment process, as investment is often characterized by inertia. Results are comparable to those reported here. Moreover, the coefficient estimate for lagged investment is not significantly different from zero, casting doubts on whether the auto-regressive model is more appropriate in our context.

\subsection{Total Factor Productivity (TFP)}

Finally, we analyze the effect of competition policy enforcement on firm-level total factor productivity. The standardized beta coefficients are reported in Table 7. Consistent with our results on competition and investment, EC merger enforcement increases TFP in the sub-sample of low-regulated countries. In particular, a one standard deviation increase in the merger enforce-

Table 7: The impact of competition policy variables on total factor productivity (TFP)

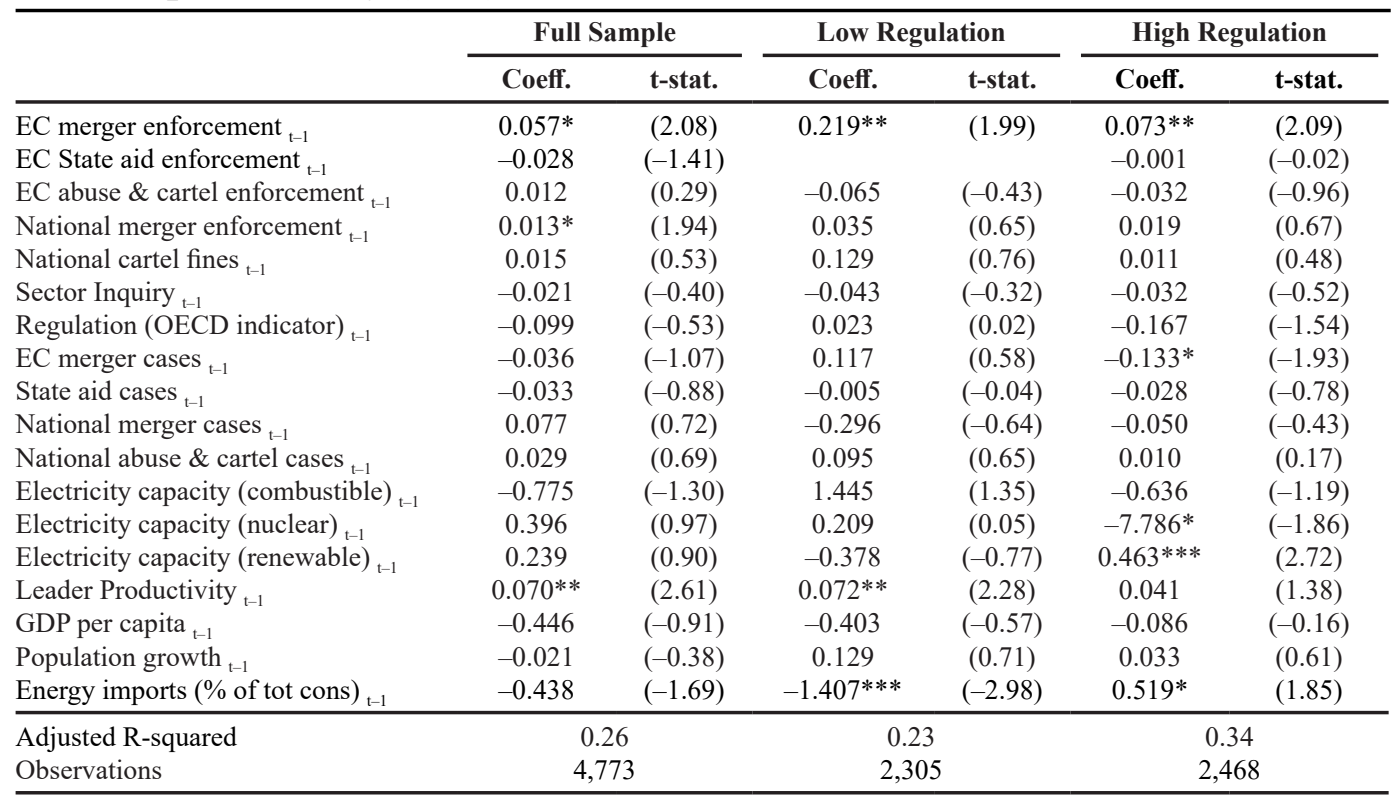

Notes: The unit of observation is firm-country-year. The dependent variable is firm level total factor productivity. All independent variables are lagged one year. We report standardized beta coefficients. Standard errors are robust and clustered at the country level. The t-statistics are reported in parentheses. We control for firm fixed-effects as well as year dummies. The symbols $* * *, * *, *$ represent $1 \%, 5 \%$, and $10 \%$ significance level respectively.

All rights reserved. Copyright (C) 2019 by the IAEE. 
ment ratio increases TFP by 0.219 standard deviations. The effect is also positive, but significantly smaller, in the full and the high regulation samples. Most other policy enforcement variables, on the other hand, have little effect on TFP.

Among the control variables, we estimate a significantly positive coefficient for the productivity level of technology leaders. This can be interpreted as a 'catching-up' effect to the productivity frontier. We also estimate a negative and significant effect of and EC-level mergers in the high-regulation sub-sample.

\subsection{Discussion of results}

One overall picture emerges: EC merger policy enforcement is consistently and significantly related to better outcomes, particularly in low-regulated sectors. EC merger policy enforcement is associated with a lower Boone's Beta, showing that energy sectors became more competitive after these interventions. A more active EC merger control is also related to higher investment and higher total factor productivity.

\section{A tentative logic}

A tentative logic for our analysis could be based on the following relationship between policy enforcement and market outcomes. First, competition policy enforcement-if well-functioning and far-reaching in its impact - directly impacts strategic interactions between firms in the involved markets, thus affecting competition (Aghion and Schankerman, 2004; Buccirossi et al., 2013). For example, some of the merger remedies put in place in the GdF/Suez merger in 2006 may have effectively been used to promote market liberalization in order to achieve effective unbundling of network and supply activities and, thus, to enhance competition (Argentesi et al., 2017); see Appendix $\mathrm{B}$ for more details on this case.

Second, there is another channel through which policy enforcement impacts competition. Each specific policy intervention not only affects the firms and markets directly involved in that specific case, but it also has indirect effects due to spill-overs across (vertical) markets (Seldeslachts et al. 2009; Clougherty and Seldeslachts, 2013; Clougherty et al., 2016). For example, specific policy decisions affecting investment in electricity generation capacity might also affect incentives and market outcomes in transmission and distribution. These indirect effects are recognized to be important elements of competition policy enforcement (Duso et al., 2013; Joskow, 2002).

In response to policy interventions and changes in competitive pressure, firms optimally adapt their investment behavior. For example, Holmes and Schmitz (2010) show that firms facing stronger competition make substantial investments to increase productivity in order to stay competitive.

Changes in market competition and firms' investment behavior might further positively impact firms' productivity, as earlier empirical evidence shows that more competition and investment can drive greater productivity (Lichtenberg and Siegel, 1991; Syverson, 2011). There are several channels through which changes in competition (policy) could lead to changes in productivity (Backus, 2014). First, competition acts as a disciplining device, placing pressure on the managers of firms to become more efficient. This decreases ' $\mathrm{X}$-inefficiency,' the difference between the most efficient behavior that the firm is capable of and its observed behavior in practice. More competition also increases productivity by reallocating resources from inefficient to efficient firms, and by forcing inefficient firms to exit. Thus, market forces may cause a reallocation in market shares from inefficient to efficient firms. Furthermore, competition drives firms to innovate and invest. Innovation 
increases firms' dynamic efficiency through technological improvements of production processes, as well as the creation of new products and services.

\section{Competition policy and regulation}

Our results are strongest in low-regulated sectors. This finding is in line with previous studies showing that competition policy is most effective where the competitive process is not influenced by high regulation (e.g. Buccirossi et al., 2013). One potential mechanism may be that if firms are highly regulated, changing the way competition works through competition policy has little impact. For example, if investment is set by the regulator then a different market structure will most likely not change it. If it is not, a different market structure may induce different behavior from market participants. Bergman et al. (1998), for example, argue that when an industry has reached a particular threshold of deregulation, competition should be introduced and safeguarded through competition policy. According to this logic, regulation and competition are substitutes. As such, competition policy's role and impact should be higher in low-regulated industries.

\section{On the causality of the relationships}

The identification of a causal nexus between competition policy enforcement and outcomes relies on being able to account for the potential endogeneity of our key policy variables. The enforcement of competition policy in some specific cases might, in principle, be focused on solving problems of under-investment or to increase productivity, which in turn might lead to correlation between enforcement and the error term in the investment or productivity equations. However, we do not examine the effect of a specific decision on the behavior of the firms involved in that specific case but focus on how the general enforcement of competition policy tools in one particular geographical market (member state) affected the behavior of all players in that market.

Regardless, to reduce the potential bias resulting from two-way causality, we use lagged values of the policy variables. This is a standard approach that relies on the assumption that the lagged values of the policy are uncorrelated with the error terms of the estimated equation. Indeed, several other studies use this type of exclusion restrictions to identify the causal effect of deregulation, competition policy, and R\&D on both investment and industry TFP growth (Alesina et al., 2005; Buccirossi et al., 2013; Bourlès, et al., 2013; Griffith et al., 2004).

Furthermore, the panel structure of our data-set allows us to control for time-invariant unobserved individual heterogeneity at the firm/sector/country level through fixed-effects, and for time fixed-effects. However, there could still be time-varying unobserved heterogeneity due to other policies correlated with competition policy enforcement affecting firms' behavior. Therefore, following the existing literature (e.g. Alesina et al., 2005; Grajek and Röller, 2012), we control for those factors that we believe are the most prominent policies affecting competition in energy markets, namely product market regulation, liberalization, and privatization captured by the OECD indexes.

Finally, we look at heterogeneous patterns in the sense that we distinguish between effects in sectors with high versus low regulation. If results differ across subsamples according to our expectation, this is an indication that our analysis is less likely to suffer from endogeneity. Indeed, it is hard to come up with a story for why an omitted shock should yield different results for different subsamples.

However, while we try to deal with issues such as reverse causality bias (by lagging the policy variables) and omitted variable bias (by using fixed effects and other controls and by finding heterogeneous effects in low and highly regulated industries), our identification strategy is not based 
on a clear source of exogenous variation since it is virtually impossible to find such exogenous variation in a broad and heterogeneous framework as is ours. We, therefore, cautiously interpret our results as illustrating strong correlations between EC merger policy enforcement and market outcomes rather than truly causal links.

Finally, policy enforcement measures other than EC merger policy show a patchier impact, i.e. a more limited correlation pattern with market outcomes. Yet, this does not conclusively prove a lack of effectiveness. It is possible that their low frequency of occurrence prevents us from empirically identifying consistent relationships.

\section{CONCLUSIONS}

This paper focuses on identifying the broad effects of competition policy enforcement on the functioning of EU energy sectors as well as its interactions with regulation. The evidence we provide paints a comprehensive picture of the different channels through which competition policy affects market outcomes: competition intensity, investment, and productivity.

Our analysis captures direct and indirect effects of these policies because it examines broad national energy sectors, capturing both the impact of policy decisions on the firms involved in competition policy cases, and on other firms active in the same market and in (vertically) connected markets.

The fact that especially EU merger policy has an impact in energy markets should perhaps not come as a surprise since the EC might have used the 'windows of opportunities' created through large European cross border merger proposals to influence energy markets (Pakalkaite, 2014). These developments could then be interpreted as competition policy tools being used with the intent to overcome significant obstacles to a well-functioning energy sector (Eberlein, 2012). Indeed, some of the remedies put in place, in principle only to mitigate the potential anti-competitive effects of mergers, may have effectively been used to promote market liberalisation in energy markets (Argentesi et al., 2017; Duso et al., 2017). Thus, one question is whether the EC has overreached by using merger control to create competition that would not have arisen absent the merger. However, as the European Court of Justice pointed out in its 2010 judgment on the ENI/EDP/GDP merger, "there is no legal impediment to the Commission pursuing liberalization of energy markets through its merger control policy, to the extent that both share the aim of increased competition" (Harrison and Mordaunt, 2012: 10/8).

More detailed retrospective research in this area is needed to shed further light on these issues. In particular, while outside the scope of this study, it would be interesting to investigate the exact channels through which competition policy impacts investment and productivity gains in energy markets. Moreover, the precise relationship between competition policy and energy regulation warrants a deeper analysis, given the importance of both policy tools in energy sectors.

\section{ACKNOWLEDGMENTS}

This paper is partially based on a project we undertook for the European Commission, Directorate-General for Competition (EC, DGComp) (ICF Consultancy Services and DIW Berlin, 2015). The opinions expressed here, however, are the sole responsibility of the authors of this paper. We thank the editor and four anonymous referees of this journal for their useful comments. Meagan Andrews, Elena Argentesi, Albert Banal-Estañol, Claude Crampes, Adriaan Dierx, Melanie Dubuis, Christian von Hirschhausen, Fabienne Ilzkovitz, Katarzyna Majkut, Peter Ormosi, Dinko Raytchev, Catherine Waddams, Charu Wilkinson, and participants at the DIW Brownbag seminar 
and CRESSE Conference 2016 for their valuable feedback. Tomaso Duso gratefully acknowledges the support of the Berlin Centre for Consumer Policies (BCCP). Jo Seldeslachts gratefully acknowledges the support of the Flemish Science Foundation (FWO).

\section{REFERENCES}

Aghion, P. and M. Schankerman (2004). "On the Welfare Effects and Political Economy of Competition-Enhancing Policies." Economic Journal 114: 800-824. https://doi.org/10.1111/j.1468-0297.2004.00244.x.

Aghion, P., R. Blundell, R. Griffith, P. Howitt, and S. Prantl (2009). "The effects of entry on incumbent innovation and productivity." Review of Economics and Statistics 91(1): 20-32. https://doi.org/10.1162/rest.91.1.20.

Alesina, A., S. Ardagna, G. Nicoletti, and F. Schiantarelli (2005). "Regulation and investment." Journal of the European Economic Association 3(4): 791-825. https://doi.org/10.1162/1542476054430834.

Altomonte, C., M. Nicolini, A. Rungi, and L. Ogliari (2010). "Assessing the Competitive Behaviour of Firms in the Single Market: A Micro-based Approach.” European Economy - Economic Papers, n. 409, Brussels.

Amir, R. (2003). "Market structure, scale economies and industry performance.” Mimeo. https://doi.org/10.2139/ssrn.995721.

Argentesi, E., A. Banal-Estanol, J. Seldeslachts, and M. Andrews (2017). "A retrospective evaluation of the GDF/Suez merger: Effects on gas hub prices.” DIW Discussion Paper, 1664. https://doi.org/10.2139/ssrn.3076821.

Backus, M. (2014). "Why is productivity correlated with competition?” In 2014 Meeting Papers (No. 726). Society for Economic Dynamics.

Bergman, L. (1998). "Europe's network industries: conflicting priorities: telecommunications.” Centre for Economic Policy Research.

Boone, J. (2008). “A New Way to Measure Competition.” The Economic Journal 118: 1245-1261. https://doi.org/10.1111/ j.1468-0297.2008.02168.x.

Boone, J., J.C. van Ours, and H. van der Wiel (2013). "When is the price cost margin a safe way to measure changes in competition?.” De Economist 161(1): 45-67. https://doi.org/10.1007/s10645-012-9196-7.

Bourlès, R., G. Cette, J. Lopez, J. Mairesse, and G. Nicoletti (2013). "Do product market regulations in upstream sectors curb productivity growth? Panel data evidence for OECD countries." Review of Economics and Statistics 95(5): 1750-1768. https://doi.org/10.1162/REST a 00338.

Brau, R., R. Doronzo, C.V. Fiorio, and M. Florio (2010). "EU gas industry reforms and consumers' prices.” The Energy Journal 167-182. https://doi.org/10.5547/ISSN0195-6574-EJ-Vol31-No4-8.

Buccirossi, P., L. Ciari, T. Duso, G. Spagnolo, and C. Vitale (2013). "Competition policy and productivity growth: an empirical assessment." Review of Economics and Statistics 95(4): 1324-1336. https://doi.org/10.1162/REST_a_00304.

Bulow, J. and P. Klemperer (1999). "Prices and the winner's curse." RAND Journal of Economics 33 (1):1-21. https://doi. org/10.2307/2696372.

Cambini, C., and L. Rondi (2010). "Incentive regulation and investment: evidence from European energy utilities." Journal of Regulatory Economics 38(1): 1-26. https://doi.org/10.1007/s11149-009-9111-6.

Clougherty, J.A., and J. Seldeslachts (2013). "The deterrence effects of U.S. merger policy instruments." Journal of Law, Economics, and Organization 29: 1114-1144. https://doi.org/10.1093/jleo/ews024.

Clougherty, J.A., T. Duso, M. Lee, and J. Seldeslachts (2016). "Effective European antitrust: Does EC merger policy generate deterrence?.” Economic Inquiry 54(4): 1884-1903. https://doi.org/10.1111/ecin.12346.

Duso T., V. Böckers, and F. Szücs (2017). "Abuse of Dominance and Antitrust Enforcement in the German Electricity Market.” DIW Discussion Paper, 1674. https://doi.org/10.2139/ssrn.3046517.

Duso, T., K. Gugler, and F. Szücs (2013). "An empirical assessment of the 2004 EU merger policy reform.” The Economic Journal 123(572): F596-F619. https://doi.org/10.1111/ecoj.12081.

Duso, T. and J. Seldeslachts (2010). "The Political Economy of Mobile Telecommunications Liberalization: Evidence from the OECD Countries.” Journal of Comparative Economics 38: 199-216. https://doi.org/10.1016/j.jce.2009.09.001.

Eberlein, B. (2012). "Inching Towards a Common Energy Policy: Entrepreneurship, Incrementalism, and Windows of Opportunity." In Constructing a policy-making state? Policy Dynamics in the EU. J. Richardson, ed.,Oxford: Oxford University Press. pp. 147-169. https://doi.org/10.1093/acprof:oso/9780199604104.003.0008.

Grajek, M. and L.H. Röller (2012). "Regulation and investment in network industries: Evidence from European telecoms." Journal of Law and Economics 55(1): 189-216. https://doi.org/10.1086/661196.

Griffith, R., S. Redding, and J. van Reenen (2004). "Mapping the two Faces of R\&D: Productivity Growth in a Panel of OECD Industries." Review of Economics and Statistics 86: 883-895. https://doi.org/10.1162/0034653043125194. 
Harrison, D. and A. Mordaunt (2012), "Mergers in the Energy Sector: An overview of EU and National Case Law." e-Competitions 49024.

Hellwig, M. (2008). “Competition policy and sector-specific regulation for network industries.” https://papers.ssrn.com/sol3/ papers.cfm?abstract_id=1275285. https://doi.org/10.2139/ssrn.1275285.

Hirschhausen, C., F. Holz, C. Gerbaulet, and C. Lorenz (2014). "Europäische Energiewirtschaft: hoher Investitionsbedarf für Nachhaltigkeit und Versorgungssicherheit." DIW-Wochenbericht, 81(27), 661-666.

Holmes, T. and J. Schmitz (2010). "Competition and Productivity: A Review of Evidence." Annual Review of Economics 2: 619-642. https://doi.org/10.1146/annurev.economics.102308.124407.

ICF Consultancy Services and DIW Berlin (2015). "The Economic Impact of Enforcement of Competition Policies on the Functioning of Energy Markets.” Study commissioned by DG Competition of the European Commission. http://ec.europa. eu/competition/ publications/reports/kd0216007enn.pdf.

Joskow, P.L. (2002). "Transaction Cost Economics, Antitrust Rules, and Remedies.” Journal of Law, Economics and Statistics 19: 95-116. https://doi.org/10.1093/jleo/18.1.95.

Lichtenberg, F.R. and D. Siegel (1991). "The impact of R\&D investment on productivity—New evidence using linked R\&DLRD data." Economic Inquiry 29(2): 203-229. https://doi.org/10.1111/j.1465-7295.1991.tb01267.x.

Lise, W. and Hobbs, B.F. (2009). "A dynamic simulation of market power in the liberalised European natural gas market.” The Energy Journal 119-135. https://doi.org/10.5547/ISSN0195-6574-EJ-Vol30-NoSI-8.

Lyon, T.P., and J.W. Mayo (2005). "Regulatory opportunism and investment behavior: Evidence from the U.S. electric utility industry.” RAND Journal of Economics 628-644.

Mulder, M. (2015). "Competition in the Dutch electricity market: an empirical analysis over 2006-2011." The Energy Journal 36(2): 1-28. https://doi.org/10.5547/01956574.36.2.1.

Pakalkaite, V. (2014). "Competence Creep Through the Backdoor: EU Energy Regulation and Competition Policy.” 5th Biennial ECPR Standing Group for Regulatory Governance Conference, Barcelona.

Pavcnik, N. (2002). "Trade liberalization, exit, and productivity improvements: Evidence from Chilean plants." The Review of Economic Studies 69(1): 245-276. https://doi.org/10.1111/1467-937X.00205.

Percebois, J. (2008). "Electricity liberalization in the European Union: Balancing benefits and risks." The Energy Journal 1-19. https://doi.org/10.5547/ISSN0195-6574-EJ-Vol29-No1-1.

Schiersch, A., and J. Schmidt-Ehmcke (2010). "Empiricism meets theory: Is the Boone-indicator applicable?" DIW Discussion Paper, 1030. https://doi.org/10.2139/ssrn.1641034.

Seldeslachts, J., J.A. Clougherty, and P.P. Barros. (2009). "Settle for now but block for tomorrow: the deterrence effects of merger policy tools." Journal of Law and Economics 52(3): 607-634. https://doi.org/10.1086/596038.

Stiglitz, J. (1989). Imperfect information in the product market. In Handbook of Industrial Organization 1. R. Schmalensee and R. Willig, eds., pp. 769-847. https://doi.org/10.1016/S1573-448X(89)01016-2.

Syverson, C. (2011). "What determines productivity?" Journal of Economic Literature 49(2): 326-365. https://doi. org/10.1257/jel.49.2.326.

Van Leuvensteijn, M., J.A. Bikker, A.A. Van Rixtel, and C.K. Sørensen (2011). “A new approach to measuring competition in the loan markets of the euro area." Applied Economics 43(23): 3155-3167. https://doi.org/10.1080/00036840903493234.

Van Leuvensteijn, M., Sørensen, C.K., Bikker, J.A. and A.A. Van Rixtel (2013). "Impact of bank competition on the interest rate pass-through in the euro area." Applied Economics 45(11): 1359-1380. https://doi.org/10.1080/00036846.2011.6176 97.

Zwart, G.T. (2009). "European natural gas markets: resource constraints and market power.” The Energy Journal 151-165. https://doi.org/10.5547/ISSN0195-6574-EJ-Vol30-NoSI-10. 


\section{APPENDIX A: DATA CONSTRUCTION}

\section{Firm and sector sample}

Firm-level data for EU energy markets was obtained from the Amadeus/Osiris database for the period 2005-2012. It contains all energy companies, including private companies. These private companies, unlike in the U.S., need to file financial reports to local regulatory bodies. ${ }^{12}$ The firms in our sample fall in the subgroups D35, Electricity, gas, steam and air conditioning supply. The few firms active in NACE D35.3, Steam and air conditioning supply, were dropped from the sample.

This database reports unconsolidated — and thus also vertically disintegrated — accountancy data for companies active in EU energy markets. For instance, there are ten different 'companies' for E.ON Germany corresponding to different firms producing, transmitting and selling energy. ${ }^{13}$ Moreover, the data are unconsolidated across countries. For example, we observe E.ON in many different countries. ${ }^{14}$ While E.ON certainly is one of the biggest and most diversified firms in our sample, all other companies are observed at such a high level of disaggregation.

We analyze those firms classified by Amadeus as 'very large,' to focus on the sizeable players in the market. This is because Amadeus contains information on more than 80,000 European firms indicated to be active in the energy sector, most of which are very small. The 25th percentile/ median/75th percentile of employees of firms are 1/2/6, with median total assets of just $€ 600,000$. Companies in Amadeus are considered to be very large when they have: operating revenue larger than $€ 100 \mathrm{~m}$, total assets larger than $€ 200 \mathrm{~m}$, or more than 1,000 employees. The firms we retain in our sample have a median of 117 employees and median fixed assets of around $€ 130 \mathrm{~m}$.

Over the entire sample period, we observe 1,438 different firms operating in 19 countries. For these firms, we collected information on variables such as total assets, fixed assets, revenue, cost of labor, and material expenditures, which are then used to build the main measures of interest. Total assets represent the sum of total current assets, long term receivables, investment in unconsolidated subsidiaries, other investments, net property plant and equipment and other assets. Fixed assets represent total assets excluding current assets, which are cash and other assets that are reasonably expected to be realized in cash, sold or consumed within one year or one operating cycle. Operating revenues is turnover. Labor costs represent the cost of staff.

Our final sample contains 19 member states: Belgium, Czech Republic, Denmark, Estonia, Finland, France, Germany, Greece, Hungary, Ireland, Italy, Netherlands, Poland, Portugal, Slovakia, Slovenia, Spain, Sweden and the United Kingdom. The most prominent countries in the sample are Germany, Italy, and the UK with shares of $24 \%, 15 \%$ and $14 \%$ of total observations, respectively. Cyprus, Luxembourg and Malta are missing from the sample because there is no firm level data for (large) energy companies in these countries. Other European countries are missing since regulation or competition policy variables are not at hand.

12. Amadeus data comes from these regulatory filings of local governments. While this is the only data source for private companies, information about public companies may come from other sources such as exchanges and press releases. See e.g. https://wrds-www.wharton.upenn.edu/pages/support/manuals-and-overviews/bureau-van-dijk/amadeus/wrds-overview-amadeus/

13. The full list is: E.ON Energie, E.ON Avacon Vertrieb GmbH, E.ON Edis Vertrieb GmbH, E.ON Hanse AG, E.ON Hanse Waerme GmbH, E.ON Kernkraft GmbH, E.ON Kraftwerke GmbH, E.ON Mitte AG, E.ON Mitte Vertrieb Gmbh, E.ON Energie Deutschland GmbH.

14. A non-exhaustive list includes: E.ON Distribucion SL, E.ON Generacion SL, E.ON Produzione Centrale Livorno, E.ON Energia SL, E.ON Espana SL, E.ON Belgium, E.ON Benelux NV, E.ON Climate and Renewables Italia, E.ON Climate and Renewables UK, E.ON Distrubuce AS, E.ON Energia SPA, E.ON Gast Sverige Aktiebolag, E.ON Nordic Aktiebolag,...

All rights reserved. Copyright (C) 2019 by the IAEE. 
Table A1 reports preliminary statistics including the yearly number of firms in the database and the yearly means and standard deviations of the selected variables (all values are in million Euros and are PPI-adjusted using a country-year specific producer price index collected from the OECD).

Unfortunately, some of the variables are missing for some of the firms over time. Specifically, the labor cost and material expenditures are the variables most likely to be missing and, therefore, reduce the sample on which we can estimate productivity measures. In the various regressions we, therefore, have different numbers of observations depending on how demanding the data requirements are.

\section{Estimation of Boone's Beta}

Following Boone et al. (2013) and Schiersch and Schmidt-Ehmcke (2010), the degree of competitive pressure is empirically measured via the relation of the firms' profits (relative to other firms in the industry) to their relative cost, which we estimate based on Amadeus data. The relative profit difference (RPD) for firm $i$, in sector $s$, in country $c$, in time $t$ is then defined as:

$$
R P D_{i s c t}=\frac{\pi_{m a x, s c t}-\pi_{\text {min,sct }}}{\pi_{i s c t}-\pi_{\text {min, sct }}}
$$

where $\pi_{\text {max } x \text { sct }}$ is defined as the profit rate (profits over revenue) of the most profitable firm in sector $s$ of country $c$ and year $t, \pi_{m i n, s c t}$ is defined as the profits of the least profitable firm in the same sector, country and year and $\pi_{i s c t}$ is defined as the profits of the focal firm. In a similar fashion, the firms' relative cost efficiency (RCE) is calculated as

$$
R C E_{i s c t}=\frac{c_{\text {max }, \text { sct }}-c_{\text {min }, \text { sct }}}{c_{\text {isct }}-c_{\text {min }, \text { sct }}},
$$

where $c$ represents the cost rate (total costs over revenue) of the most profitable firm in sector $s$ of country $c$ and year $t$.

We estimate the equation for three national energy sectors, namely generation and production, transmission and distribution, and trade. Specifically, we run a pooled regression where we

Table A1: Mean and variance of Amadeus variables (PPI-adjusted million $€$ )

\begin{tabular}{ccccccc}
\hline Year & \# Firms & $\begin{array}{c}\text { Revenue } \\
(\text { VA) }\end{array}$ & $\begin{array}{c}\text { Total Assets } \\
(\mathbf{K})\end{array}$ & $\begin{array}{c}\text { Fixed Assets } \\
(\text { FA) }\end{array}$ & $\begin{array}{c}\text { Labor Cost } \\
(\mathbf{L})\end{array}$ & $\begin{array}{c}\text { Material Expend. } \\
(\mathbf{M})\end{array}$ \\
\hline 2005 & 902 & 773.65 & $1,264.16$ & 882.26 & 62.79 & 546.35 \\
& & $(2865)$ & $(7021)$ & $(5161)$ & $(414)$ & $(1915)$ \\
2006 & 1021 & 836.32 & $1,191.54$ & 828.88 & 60.87 & 640.76 \\
& & $(2720)$ & $(5721)$ & $(4415)$ & $(309)$ & $(2105)$ \\
2007 & 1149 & 785.81 & $1,251.79$ & 870.37 & 56.80 & 565.18 \\
& & $(2927)$ & $(6823)$ & $(4976)$ & $(373)$ & $(1965)$ \\
2008 & 1244 & 761.64 & $1,175.59$ & 809.13 & 45.07 & 578.53 \\
& & $(2498)$ & $(5392)$ & $(4014)$ & $(217)$ & $(1875)$ \\
2009 & 1325 & 775.21 & $1,343.40$ & 977.50 & 52.11 & 556.99 \\
& & $(2819)$ & $(8078)$ & $(6185)$ & $(375)$ & $(1954)$ \\
2010 & 1344 & 783.10 & $1,355.57$ & 970.77 & 49.27 & 553.84 \\
& & $(2896)$ & $(7889)$ & $(5949)$ & $(382)$ & $(1973)$ \\
2011 & 1365 & 775.34 & $1,256.22$ & 898.21 & 42.01 & 564.84 \\
& & $(2581)$ & $(5735)$ & $(4382)$ & $(220)$ & $(1975)$ \\
2012 & 1329 & 791.48 & $1,282.31$ & 922.60 & 41.96 & 579.20 \\
& & $(2708)$ & $(5948)$ & $(4618)$ & $(229)$ & $(2051)$ \\
\hline
\end{tabular}

Notes: Standard deviations in parentheses. 
regress the log of RPD on the log of RCE and identify separate coefficients for each sector, country, and year:

$$
\ln R P D_{i s c t}=\alpha+\beta_{s c t} \ln R C E_{i s c t}+\varepsilon_{i s c t} .
$$

As a measure of profit we use the variable 'profit and loss,' while as a measure of revenue we use the variable 'operating revenues' from Amadeus. As a measure of cost we use the variable 'Cost of goods sold' from Amadeus (e.g. Altomonte et al., 2010).

We apply multiple layers of quality control: First, we drop the top and bottom percentiles of normalized profits and normalized costs (based on which Boone's Beta is estimated). Second, we check for each country/industry/year cluster whether sufficient data for estimation are available. Finally, we manually drop a few outliers. The resulting Betas, averaged over all countries, are shown in Table 4 in the main text. Note that while we estimate Boone's Beta for the different segmentsproduction, transmission, and trade - for each country and year in a total of 396 regressions, to increase econometric efficiency and number of observations we pool these sectors when we look at the impact on competition policy enforcement on Boone's Beta. Because of the layers of quality control, we lose several of the potential 396 observations. Indeed, the regressions using the Boone's Betas as dependent variable are run on a sample of 251 observations.

\section{Estimation of total factor productivity (TFP)}

We calculate total factor productivity of firm $i$ in sector $s$, in country $c$, in year $t$ as the residual of a sector-specific $(s)$, translog production function:

$$
T F P_{i s c t}=\ln V A_{i s c t}-f_{s}\left(\ln K_{i s c t}, \ln L_{i s c t}, \ln M_{i s c t}\right),
$$

where $V A_{i s c t}$ is the value added of firm $i$ in year $t, K_{i s c t}, L_{i s c t}$, and $M_{i s c t}$ represent its capital (as measure by total assets), labor (as measured by staff costs) and material expenditures, respectively. Note that as a proxy for value added we use the log of operating revenues (which are a measure of turnover). For Denmark, Ireland and the UK no data on material expenditures are available; we proxy for these values by calculating the difference between total cost and staff expenditures.

The sector $s$ specific production function $\mathrm{f}_{\mathrm{s}}($.$) is a trans-log specification comprising all$ interactions of $\ln K^{j}, \ln L^{j}$, and $\ln M^{j}$ with $j \leq 2$ (for a total of 20 terms of up to degree 6) as well as year fixed-effects and firm fixed-effects. This functional form can be interpreted as a Taylor approximation to a general, but unknown, production function. The sector-specific production function is estimated separately for firms in the production, transmission, and trade sectors. To control for outliers, we drop top and bottom percentiles of calculated productivities. The results of the estimation in the specific sub-samples are reported in Table A2.

The models perform well as they are able to explain more than $90 \%$ of the variation in the $\log$ turnover. They also produce reasonable coefficient estimates for the marginal productivities. Specifically, we can calculate the average marginal productivity for each input at the mean value of the other inputs. We estimate an average marginal productivity of labor between 0.11 and 0.36 , an average productivity of materials between 0.28 and 0.55 and an average marginal productivity for capital between 0.26 and 0.45 . 
Table A2: Production function estimations

\begin{tabular}{|c|c|c|c|c|c|c|}
\hline & \multicolumn{2}{|c|}{ Production } & \multicolumn{2}{|c|}{ Transmission } & \multicolumn{2}{|c|}{ Trade } \\
\hline & Coeff. & t-stat. & Coeff. & t-stat. & Coeff. & t-stat. \\
\hline Capital & $-0.173^{*}$ & $(-1.78)$ & $0.468^{* * * *}$ & $(4.95)$ & $0.799^{* * * *}$ & $(7.95)$ \\
\hline Labor & $0.378^{* * * *}$ & $(4.32)$ & $0.381^{* * * *}$ & $(4.47)$ & $-0.209^{*}$ & $(-1.72)$ \\
\hline Materials & $0.409^{* * * *}$ & (7.33) & $0.431^{\text {****k }}$ & $(6.45)$ & $0.751^{* * * *}$ & $(19.22)$ \\
\hline Capital $^{2}$ & $0.081^{* * *}$ & $(7.27)$ & -0.013 & $(-1.27)$ & 0.017 & $(1.26)$ \\
\hline Labor $^{2}$ & $0.059^{* * *}$ & $(5.73)$ & $0.047^{* * * *}$ & $(2.81)$ & -0.008 & $(-0.41)$ \\
\hline Materials $^{2}$ & $-0.036^{* * *}$ & $(-4.14)$ & $0.092^{* * *}$ & $(10.50)$ & $0.113^{* * *}$ & $(16.51)$ \\
\hline Labor*Capital & $-0.067^{* *}$ & $(-2.14)$ & -0.006 & $(-0.22)$ & $0.213^{* * * *}$ & $(4.61)$ \\
\hline Labor*Materials & $-0.046^{* * * *}$ & $(-2.82)$ & $-0.137^{* * * *}$ & $(-6.68)$ & $-0.058^{* * * *}$ & $(-3.16)$ \\
\hline Capital*Materials & 0.030 & $(1.36)$ & $-0.047^{*}$ & $(-1.69)$ & $-0.256^{* * *}$ & $(-13.08)$ \\
\hline Capital*Materials*Labor & $0.005^{* *}$ & $(1.98)$ & $0.008^{* *}$ & $(2.30)$ & 0.001 & $(0.24)$ \\
\hline Labor $^{2 *}$ Materials & $-0.007^{* * *}$ & $(-6.08)$ & $-0.009^{* * *}$ & $(-9.31)$ & $0.006^{* * *}$ & $(3.02)$ \\
\hline Labor $^{2 *}$ Capital & -0.002 & $(-0.94)$ & -0.006 & $(-1.04)$ & -0.010 & $(-1.60)$ \\
\hline Capital $^{2 *}$ Labor & 0.004 & $(1.26)$ & -0.001 & $(-0.39)$ & $-0.025^{* * * *}$ & $(-5.54)$ \\
\hline Capital $^{2 *}$ Materials & $-0.009^{* * * *}$ & $(-4.10)$ & 0.004 & $(1.20)$ & $0.024^{* * * *}$ & $(9.00)$ \\
\hline Materials ${ }^{2 *}$ Labor & $0.005^{* * *}$ & $(6.61)$ & $0.009^{* * * *}$ & $(8.83)$ & $0.008^{* * * *}$ & $(5.50)$ \\
\hline Materials ${ }^{2 *}$ Capital & $0.018^{* * * *}$ & $(7.32)$ & $-0.015^{* * *}$ & $(-5.34)$ & $-0.013^{* * *}$ & $(-6.61)$ \\
\hline Labor $^{2 *}$ Capital $^{2}$ & -0.000 & $(-0.44)$ & $0.001^{*}$ & $(1.90)$ & $0.002^{* * * *}$ & $(2.74)$ \\
\hline Labor $^{2 *}$ Materials ${ }^{2}$ & -0.000 & $(-1.07)$ & 0.000 & (1.04) & $-0.001^{* * * *}$ & $(-4.04)$ \\
\hline Materials $^{2 *}$ Capital $^{2}$ & $-0.001^{* * *}$ & $(-6.86)$ & $0.001^{* *}$ & $(2.31)$ & 0.000 & $(0.30)$ \\
\hline Capital $^{2 *}$ Labor $^{2 *}$ Materials $^{2}$ & $0.000^{* * * *}$ & $(3.41)$ & -0.000 & $(-0.84)$ & 0.000 & $(0.01)$ \\
\hline Constant & $1.516^{* * *}$ & (6.34) & $1.161^{* * * *}$ & $(5.29)$ & $-0.674^{* * * *}$ & $(-3.23)$ \\
\hline R-squared & \multicolumn{2}{|c|}{0.953} & \multicolumn{2}{|c|}{0.975} & \multicolumn{2}{|c|}{0.952} \\
\hline Observations & \multicolumn{2}{|c|}{2,862} & \multicolumn{2}{|c|}{2,327} & \multicolumn{2}{|c|}{1,929} \\
\hline
\end{tabular}

Notes: The level of observation is country-firm-year. The dependent variable is the country-firm-year specific log of operating revenues. Capital, Labor and Materials are in logs as well. Standard errors in parentheses are robust and clustered at the country-sector level. The t-statistics are reported in parentheses. We control for firm fixed-effects as well as years. The symbols $* * *, * * *$ represent $1 \%, 5 \%$, and $10 \%$ significance level respectively

\section{APPENDIX B: TWO EXAMPLES OF COMPETITION POLICY ENFORCEMENT IN EU ENERGY MARKETS}

We provide here two examples that cover different sectors and countries, degrees of regulation, and competition policy interventions.

\section{EU abuse of dominance case - E.ON cases COMP/B-1/39.388-German Electricity Wholesale Market and COMP/B-1/39.389—German Electricity Balancing Market}

In 2008, the European Commission (EC) investigated E.ON, a large and vertically integrated German electricity company, for an alleged abuse of dominance. The EC said that E.ON (i) withdrew capacity from short-term energy markets to reduce competition and (ii), deterred independent investment in capacity through long-term supply contracts and offering potential entrants participation in existing E.ON plants. Despite contesting the accusations, E.ON agreed to divest a total of $5 \mathrm{GW}$ generation capacity and its ultra-high voltage transmission network. The Commission, as well as most competitors questioned in the market investigation, found these divestitures sufficient to address all competitive concerns raised and the investigation was closed (see Duso et al., 2017, for more details on this case).

This case is coded in our data as an EC abuse of dominance case in 2008 in the German electricity market. At the time of the decision, the German electricity sector was according to our dataset considered to be a low-regulated market. 


\section{EU Merger case - Case No COMP/M.4180 — Gaz de France/Suez}

The EC started an investigation beginning 2006 of Gaz de France's (GdF) acquisition of Suez, which created one of the world's largest energy companies and affected the gas market at several stages of the supply chain in Belgium and France. The EC raised competition concerns about the elimination of an important competitor through the merger, plus the creation of barriers to entry for other potential competitors. Moreover, the EC feared reduced incentives to invest in infrastructure. The merger received approval in November 2006, after the merging parties proposed a series of remedies, both structural (the divestment of some important assets) and behavioral (through the promise to invest in infrastructure post-merger); see Argentesi et al. (2017) for more details on this case.

As the EC started its investigation in that year, this case is coded in our data as an EU merger in 2006 and an EU merger enforcement case in 2006, since the merger with remedies got approved at the end of 2006. The markets were this merger was allocated were the French and Belgian gas markets. At the time of the merger, the French and Belgian sectors were according to our dataset considered to be a high-regulated markets. 